\title{
Ectopic Hamartomatous Thymoma
}

National Cancer Institute

\section{Source}

National Cancer Institute. Ectopic Hamartomatous Thymoma. NCI Thesaurus. Code C53595.

A benign, well-circumscribed tumor of the neck occurring in adults. It is characterized by the presence of spindle cells, epithelial islands, and adipose tissue. There is no evidence of thymic origin or differentiation, despite the use of the term thymoma in the literature. 